\title{
Diurnal activity patterns of the temporary fish ectoparasite, Gnathia africana Barnard, 1914 (Isopoda, Gnathiidae), from the southern coast of South Africa
}

\author{
RACHEL L. WELICKY ${ }^{1}$, MARYKE L. FERREIRA ${ }^{2}$, PAUL SIKKEL ${ }^{1,3}$ AND NICO J. SMIT ${ }^{1}$ \\ ${ }^{1}$ Water Research Group, Unit for Environmental Sciences and Management, North-West University, Potchefstroom Campus, \\ Private Bag X6001, Potchefstroom, 2520, South Africa, ${ }^{2}$ Department of Zoology, University of Johannesburg, Auckland Park, 2006, \\ South Africa, ${ }^{3}$ Department of Biological Sciences, Arkansas State University, State University, P.O. Box 599, AR, 72467, USA
}

\begin{abstract}
Gnathiid isopods are one of the most common fish ectoparasites, and are found in both temperate and tropical oceans. On coral reefs, gnathiids are most active at dusk and dawn, and contribute significantly to trophic dynamics, as they are a prey resource for cleaner fish and parasitize numerous fishes. Gnathiids also inhabit temperate intertidal waters, but their activity patterns and contribution to intertidal trophic dynamics remain unstudied. To provide the first ecological data on temperate intertidal gnathiid activity patterns, 172 gnathiid-free Clinus superciliosus were set in an intertidal system in Tsitsikamma National Park, South Africa, during early morning, morning, afternoon, early evening, and evening, high and low tide, and within the inter-and infra-tidal zone to examine gnathiid infestation levels. After exposure, gnathiids from each fish were identified to the species level, counted, and their developmental stage was recorded. All gnathiids were identified as Gnathiia africana. On average, $1 \pm 5 S D$ gnathiids were collected from each fish, and the majority of gnathiids collected were stage 1. Significantly more gnathiids were collected during morning and afternoon compared with all other time periods. The number of gnathiids collected was not influenced by the fish's exposure to high or low tide, or placement within the tide zone. Although $\mathrm{G}$. africana is free from cleaner fish predation because cleaner fish do not reside in temperate intertidal habitat, G. africana abundance is surprisingly small. Future studies should examine what regulates G. africana population size and the role they play in temperate intertidal food webs.
\end{abstract}

Keywords: Activity patterns, Clinus superciliosus, diel, intertidal, isopod, gnathiid, klipfish, symbiosis, temperate, trophic interactions Submitted 19 April 2017; accepted 19 June 2017; first published online 23 August 2017

\section{INTRODUCTION}

Many marine organisms undergo daily shifts in activity. These daily shifts are often associated with the exploitation of food, avoidance of predators, and reproductive efforts (e.g. Sancho et al., 2000; Zemke-White et al., 2002). Such diel activity patterns are also correlated with multiple environmental cues, including lunar periodicity and ambient light (Naylor, 1999; Tessmar-Raible et al., 2011), tide cycles (Palmer, 2000; Gibson, 2003), and physiological cues derived from circadian rhythms (Reebs, 2002; Connor \& Gracey, 2011).

The diel activity patterns of small, mobile, benthic invertebrate zooplankton are particularly well-documented. These organisms regularly undergo daily vertical migrations. In both marine and freshwater environments, they find refuge from fish predators in the benthos during daytime, and move up the water column at night, where food is typically more dense and easier to locate (Gilbert \& Hampton, 2001;

Corresponding author:

R.L. Welicky

Email: rwelicky@gmail.com
Hays, 2003). Although the diel activity patterns of zooplankton may be in part related to endogenous cues, there is evidence that they can moderate their activity levels based on factors such as light availability, which in turn are associated with season and time of day (Hays, 1995; Cohen \& Forward, 2009).

Isopods of the family Gnathiidae are a major part of the community of small, mobile, benthic invertebrates in marine systems (Hobson \& Chess, 1976; Hammer \& Zimmerman, 1979; Hammer, 1981; Jacoby \& Greenwood, 1988). They inhabit both temperate and tropical oceans (Smit \& Davies, 2004; Ferreira et al., 2009; Sikkel \& Welicky, in press). Gnathiids are considered one of the most common ectoparasitic groups found infecting marine fishes (Grutter, 1994; Grutter \& Poulin, 1998a, b; Coile \& Sikkel, 2013) as they infest hosts during each of three juvenile stages. After the final feeding, they metamorphose into non-feeding sexually dimorphic adults (Smit \& Davies, 2004; Ferreira et al., 2010; Farquharson et al., 2012). Thus, most of their fish-parasitic juvenile stages and all of their adult stage are spent free-living. Gnathiids can impact fish hosts in multiple ways. They can alter host physiology through reduced haematocrit (Jones \& Grutter, 2005), increased levels of corticosteroid stress hormones (Triki et al., 2016), and the creation of wounds that 
can lead to secondary infection (Bunkley-Williams \& Williams, 1998). They may transmit blood-borne parasites (Smit \& Davies, 2004; Curtis et al., 2013), and in extreme cases can cause host mortality in adult-size fish (BunkleyWilliams \& Williams, 1998; Hayes et al., 2011). Gnathiids can even infest and kill settlement-stage fishes (Grutter et al., 2008, 2011a; Penfold et al., 2008; Artim et al., 2015). Gnathiids on coral reefs play a major role in marine cleaning symbioses where they are the main food item for cleaner fishes (e.g. Côté, 2000; Grutter, 2002) and appear to influence the interaction of fish hosts with cleaners (Grutter, 1999; Côté \& Molloy, 2003; Sikkel et al., 2004, 2005). These cleaning interactions have been reported to play a significant role in coral reef community dynamics (Waldie et al., 2011; reviewed by Sikkel \& Welicky in press).

Although gnathiids have a near global distribution, the majority of studies examining gnathiid activity patterns have been conducted on tropical species in the Pacific and Caribbean. Activity patterns at some Great Barrier Reef sites tend to peak during new and full moon (Jacoby \& Greenwood, 1988; Grutter et al., 2000), whereas Caribbean gnathiid activity patterns show little correlation with lunar periodicity (Welicky et al., 2013). Studies in both the Caribbean and Pacific have demonstrated a correlation between gnathiid activity and time of day, where infestation by gnathiids peaks at dawn and/or night, and daytime activity is considerably lower (Grutter, 1999; Grutter \& Hendrikz, 1999; Chambers \& Sikkel, 2002; Sikkel et al., 2006, 2009; Jones \& Grutter, 2007). Accordingly, gnathiids in shallow coral reef habitats appear to be predominantly nocturnal.

In contrast to the myriad of ecological research on coral reef gnathiids, ecological information on intertidal gnathiids is limited. Intertidal habitats are often less accessible due to the high-energy wave action of these areas. Accordingly, studies within these areas are difficult to conduct. The ecological data currently available on intertidal gnathiids have been extrapolated mainly from studies on a closely related genus, Elaphognathia (Tanaka \& Aoki, 1998, 1999), as well as gnathiid taxonomy (Smit et al., 2002; Hadfield et al., 2008), life cycle (Smit et al., 2003; Hadfield et al., 2009), and fish blood haemogregarine studies (Davies \& Smit, 2001; Davies et al., 2004). From studies examining the distribution of Elaphognathia, we know that the density of Elaphognathiid larvae is greatest at the midpoint between high and low tide, and the overall distribution of Elaphognathiids spans the entire distribution of their sponge habitat, and they are observed throughout the year (Tanaka \& Aoki, 1998; Tanaka \& Aoki, 1999).

Gnathia africana Barnard, 1914 is one of the few intertidal gnathiid species that has been studied in detail, and its morphology (Smit et al., 1999, 2002) and full life cycle (Smit et al., 2003) have been described. Gnathia africana has been collected from the intertidal of the temperate south and cold west coasts of southern Africa, where it inhabits sponge and infects Clinus superciliosus Linnaeus, 1758 (Smit et al., 1999). Gnathia africana metamorphose from larvae to adult male and female over $\sim 34$ and 41 days, respectively, and can survive in waters from $8-25^{\circ} \mathrm{C}$ (Smit et al., 2003). Despite extensive taxonomic research on this species, no ecological studies for this species have been conducted.

The goal of this study is to provide the first steps towards understanding the ecology of intertidal gnathiids by examining the interactions between G. africana and its host Clinus superciliosus. Given that time of day influences the activity patterns of other gnathiid species, and environmental factors associated with tidal cycles play a significant role in shaping intertidal ecosystem dynamics, the primary objectives of this study were to quantify G. africana activity patterns with respect to time of day, tidal zone and tidal cycle.

\section{MATERIALS AND METHODS}

\section{Study area and site selection}

Tsitsikamma National Park (TNP) (34 $01^{\prime} 16.35^{\prime \prime} \mathrm{S}$ $\left.23^{\circ} 53^{\prime} 43.87^{\prime \prime} \mathrm{E}\right)$ is situated in the southern Cape of South Africa, and is one of the largest Marine Protected Areas (MPA) in the world, and the oldest MPA in South Africa (Turpie et al., 2006) (Figure 1). The shoreline consists of steep rocky cliffs, with occasional sandy beaches. Since 1964, TNP has been closed to fishing (Sauer et al., 1997), and thereby provides a refuge for fishes and other marine animals, as well as pristine sampling habitat for such organisms.

\section{Fish and parasite sampling protocol}

Fish were caught using baited hooks and line during April 2007, July 2008 and November 2008. Identity of captured fish was confirmed using Smith \& Heemstra (2003), total length (TL) was measured (in $\mathrm{cm}$ ), and fish were held in buckets of fresh, aerated seawater for $\sim_{3} \mathrm{~h}$ to allow attached gnathiid juveniles (pranizae) to complete their feeding and dislodge from the host fish naturally (Figure 2). These 'gnathiid free' $C$. superciliosus were placed into cages and exposed to the sea for a period of $4 \mathrm{~h}$, except for those that were set for the early morning retrieval and were set for $\sim 8 \mathrm{~h}$. The cages were set within the following intervals, which were modified from Grutter (1999) and Chambers \& Sikkel (2002): early morning $(\sim 2200-0800)$, morning (0600-1200), afternoon (1000-1600), early evening (1400$1900)$, evening $(1800-2400)$. The cages were constructed of galvanized steel and mesh, and the dimensions of each cage were $\sim 30 \mathrm{~cm}$ wide by $30 \mathrm{~cm}$ high. The mesh opening allowed for water and zooplankton to easily flow through the cage. The cages were set within the intertidal or infratidal zone, and during periods of both high and low tide. Infratidal was defined as the zone below the low tide mark, and the intertidal zone was defined as the zone between the high and low tide marks. Following retrieval, fish were removed from cages, placed in resealable plastic bags filled with seawater, and transported to the mobile research station inside TNP. At the mobile station, aerators were inserted into the fish's bag to oxygenate the water. After 24 h, C. superciliosus were released, and the water in which they were held was sieved and screened for gnathiids. Gnathiid juveniles were all identified as Gnathia africana from Smit et al. (1999), and were mainly pranzia (fed gnathiids). Few zuphea (unfed gnathiids) were also obtained and these were gnathiids that detached from hosts but did not complete their feeding. Zuphea were included in gnathiid counts as they were attached to the fish upon collection. The number and feeding stages of pranizae/zuphea collected from each fish were recorded and divided into first, second and third stages based on size and morphology (Smit et al., 1999; Smit \& Davies, 2004). 


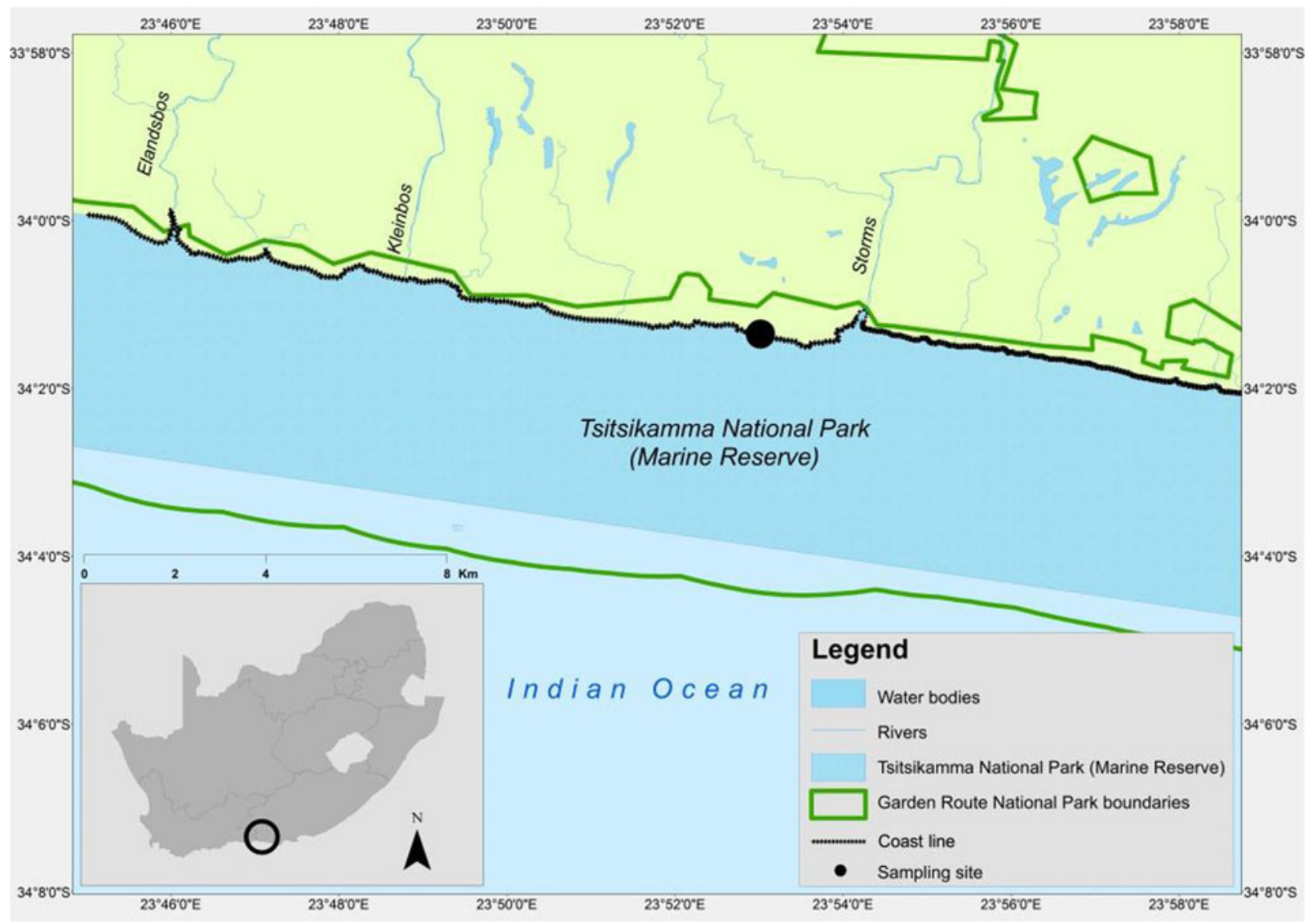

Fig. 1. Map of study site within Tsitsikamma National Park, South Africa.

\section{Statistical analyses}

A relationship between fish body size and ectoparasite load has been reported in other studies (e.g. Grutter \& Poulin, 1998b; Poulin, 2000). Thus, the relationship between fish length and gnathiid load was assessed to determine whether fish length should be included as a covariate in the analyses described below (Coile \& Sikkel, 2013; Coile et al., 2014).

The statistical analyses explained hereafter used the independent variables collection period, tide, tide zone and time. The variable collection period had three levels, one per collection period (April, July, November). The variable tide had two levels, high and low tide. Tide zone also had two levels, infratidal and intertidal. Time was divided into five levels, one per time interval (see above). There were four dependent variables, which were assessed separately: the total number of gnathiids (all stages combined), stage 1 gnathiids, stage 2 gnathiids and stage 3 gnathiids.

To examine if any of the independent variables were predictors of the dependent variables, bootstrapped analyses of variance with 10,000 replications (with replacement) were conducted. Bootstrapped analyses of variance were conducted as raw data were not normally distributed following transformation, the dataset was small with a small range in values, and contained many zero counts (Artim \& Sikkel, 2016). By conducting bootstrapped analyses of variance with $95 \%$ confidence intervals, we were able to approximate the true distribution of the dataset and assess the effects of the independent variables on the dependent variables. Interaction effects among the independent variables were not included in the analyses as they are not biologically relevant, and were controlled for throughout sampling. For example, although high and low tide changes daily, cages were always set according to that day's high and low tide, and within the respective infratidal and intertidal zones.

For each dependent variable, two bootstrapped analyses of variance were conducted (as described above). In the first analysis all independent variables were used. In the second analysis, only those variables which were significant at the $P=0.1$ level in the first analysis were included. The second analysis was conducted to ensure the large number of independent variables would not mask factors that were significant. Post-hoc comparisons of significant predictors from the second analysis are reported. All descriptive statistics are reported as mean $\pm \mathrm{SD}$.

\section{RESULTS}

\section{Descriptive statistics}

Over the course of the study, 172 C. superciliosus (April, $\mathrm{N}=$ 57; July, $\mathrm{N}=41$; November $=74$; mean $\mathrm{TL}=15.4 \mathrm{~cm} \pm$ 2.3) were used for sampling. Details of the number of fish collected and tested by tide zone and time of day are reported in Table 1. In April, July and November, the mean total number of gnathiids collected per fish was $2 \pm 5,3 \pm 8$, and $o+1$, respectively. The overall mean number of total gnathiids collected per fish was $1 \pm 5$, and this was not 


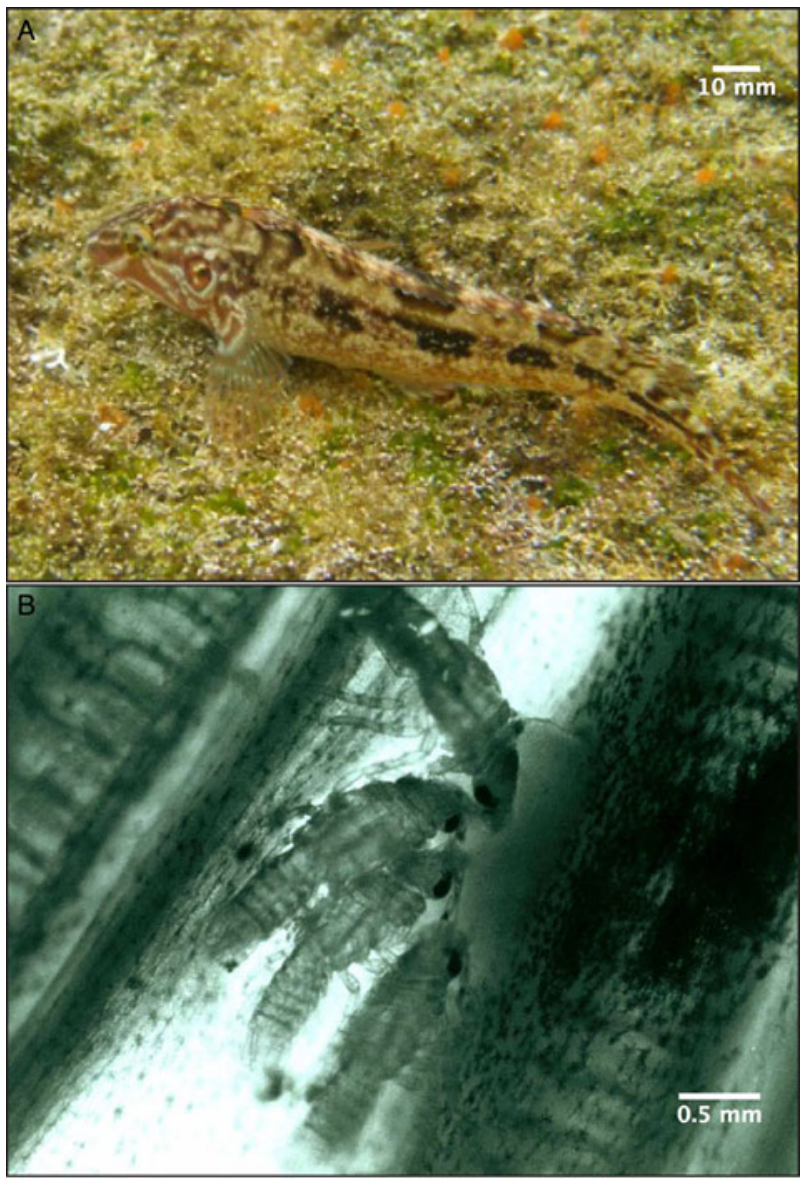

Fig. 2. (A) Clinus superciliosus. (B) Gnathia africana parasitizing Clinus superciliosus. Photos courtesy of N. J. Smit.

correlated with TL $\left(r^{2}=0.000, P=0.877\right)$. The mean total number of gnathiids was greatest during morning and afternoon, and lowest during early morning (Figure 3). The average number of stage 1,2 and 3 gnathiids collected was $0+4,0+1$ and $o+1$, respectively. The TL data were not correlated with the number of stage $1\left(r^{2}=0.003, P=0.437\right)$, $2\left(r^{2}=0.009, P=0.224\right)$ and $3\left(r^{2}=0.007, P=0.263\right)$ gnathiids.

\section{Total number of gnathiids}

In the first analysis, tide was not a significant predictor of total number of gnathiids (Table 2). In the second analysis, both tide zone and collection period were not significant predictors of the total number of gnathiids collected (Table 2). The time

Table 1. Sample sizes of the number of fish used in the study by time of day and tide zone.

\begin{tabular}{lll}
\hline Time & \multicolumn{2}{c}{ Tide zone } \\
\cline { 2 - 3 } & Infratidal & Intertidal \\
\hline Early morning (2200-0800) & 12 & 23 \\
Morning (0600-1200) & 13 & 21 \\
Afternoon (1000-1600) & 16 & 23 \\
Evening (1400-1900) & 16 & 22 \\
Late evening (1800-2400) & 9 & 17 \\
\hline
\end{tabular}

at which caged fish were collected significantly influenced the total number of gnathiids present (Table 2). There were significantly more gnathiids collected in afternoon compared with evening and early morning, and there were significantly fewer gnathiids collected in early evening, evening and early morning compared with morning (Table 3). Thus gnathiid activity was greatest during morning and afternoon.

\section{Number of gnathiids by developmental stage}

In the first and second analyses, time of day was a significant predictor for the number of stage 1 and 2 gnathiids (Table 2). There were significantly fewer stage 1 gnathiids collected during early evening, evening, and early morning compared with morning (Table 3 ). Significantly more stage 2 gnathiids were collected in the afternoon compared with early evening and early morning, and there were significantly more stage 2 gnathiids collected in early evening compared with early morning and evening (Table 3 ). In the first and second analyses of stage 1 gnathiids, collection period was a significant predictor, such that similar numbers of stage 1 gnathiids were collected in July and April $(P=0.077)$ and fewer were collected in November as compared with July $(P=0.025)$ and April $(P=0.044)$. No other predictors significantly influenced the number of stage 1,2 and 3 gnathiids in both the first and second analyses (Table 2).

\section{DISCUSSIDN}

This study is the first to report on the abundance and diel activity patterns of temperate gnathiids. Whereas tropical reef gnathiids have been reported as generally more abundant and most active at night, the findings of this study indicate that temperate intertidal gnathiids may be more active during the day, independent of the tide cycle and tidal zones.

The number of intertidal gnathiids collected from C. superciliosus at this site was much smaller than those typically collected from coral reef habitats (Grutter \& Poulin, 1998b; Grutter, 1999, 2008; Coile \& Sikkel, 2013; Welicky et al., 2013; Sikkel et al., 2017). There are at least three possible explanations for this difference. First, the fish species composition and the nature and diversity of feeding modalities vary greatly between these two systems. Whereas on coral reefs, cleaner fish and shrimp prey upon gnathiids during the day, in the intertidal, some small Clinus spp. forage on gnathiids (Bennett et al., 1983) and Clinus spp. may forage on gnathiids throughout the day. Clinus spp. may forage continually, and it has been suggested that C. superciliosus may consume $\sim 21 \%$ of the available small crustacean, polychaete and mollusc prey items within their habitat (Bennett, 1984; Gibbons, 1988). If other resident intertidal fish consume similar prey items, such fish would consume $64 \%$ of the available items (Bennett, 1984). This intense predation could contribute to and greatly reduce the overall gnathiid population size. Secondly, the smaller number of gnathiids observed in this intertidal system as compared with coral reef studies may be associated with the generally stronger and more frequent wave action observed in the intertidal $v s$ reef system (e.g. Abelson \& Denny, 1997). High wave action could reduce the swimming and attachment capacity of gnathiids, and thus reduce their success of infesting hosts. However, this explanation is unlikely because there were no significant 


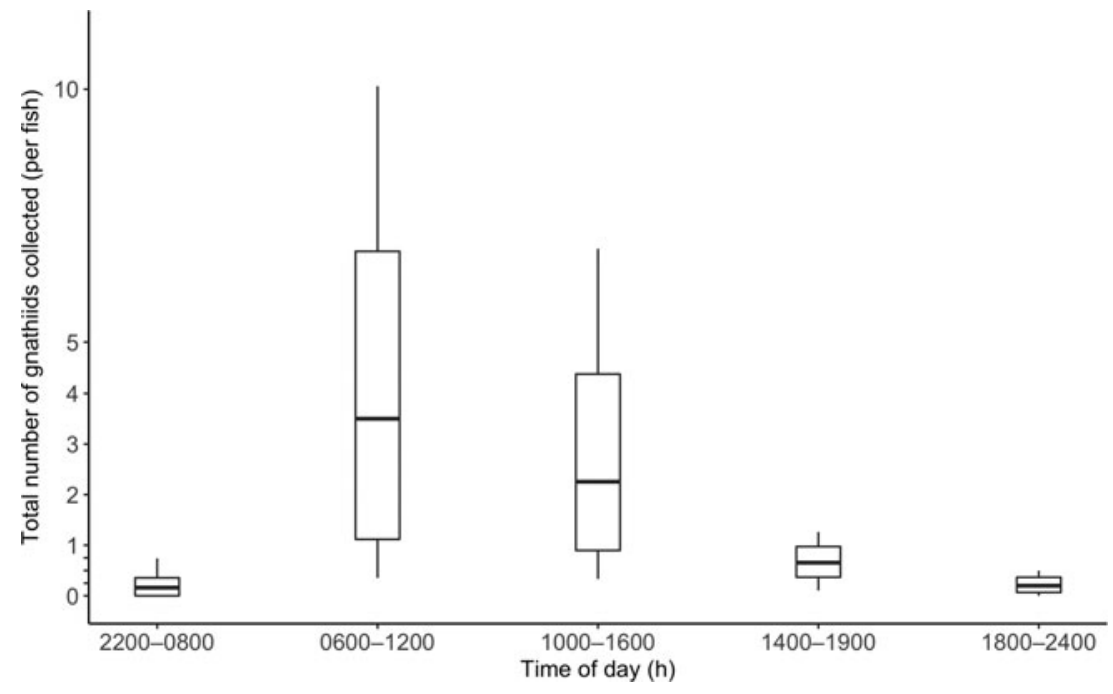

Fig. 3. Total number of gnathiids collected per fish by time of day. Boxplot values were calculated using bootstrapping with 10,000 replications. The centreline is the mean total number of gnathiids collected per fish, the lower and upper box lines indicate the $95 \%$ confidence interval, and the lower and upper stems indicate the minimum and maximum number of gnathiids collected per fish, respectively. No lower stems are depicted for values below o, as o is the least number of gnathiids possibly collected.

differences in the number of gnathiids collected between high and low tide, and if gnathiids infested hosts more easily in calmer water, then significantly more gnathiids should have been collected during low tide in the intertidal pools. A third and more plausible alternative is that G. africana appears to feed on a narrow range of hosts (Smit \& Davies, 1999), and to be a habitat specialist. Generally, intertidal systems are less diverse than reef systems and may have fewer host species available (Stuart-Smith et al., 2013). It is conceivable that G. africana have a preference for a particular host species as other gnathiids are considered generalists with preferences (Jones et al., 2007; Nagel \& Grutter, 2007), and the preferred hosts for G. africana may be less abundant than the preferred hosts in coral reef systems. Thus, the small number of gnathiids collected in this study may be associated with fish using gnathiids as a predominant prey resource, and/or host and habitat availability being limited.

The numbers of gnathiids collected from fish were similar among tidal cycles and zones, and this likely reflects the relatively expansive movement and distribution of both susceptible hosts and gnathiids. In a mark and recapture study of Clinus spp., fish were reported to move mainly during high tide, recaptures occurred only half the time, and those recaptured were within $0-4 \mathrm{~m}$ of the locality in which they were first observed (Marsh et al., 1978). Given that the fish themselves may serve as a mechanism of transport and dispersal (Sikkel et al., 2017), infected C. superciliosus that do move among tidal pools at high tide probably facilitate the transport and distribution of gnathiids between and within the inter and infratidal zones. Fish that remain within the same locality over

Table 2. Results of bootstrapped analyses of variance.

\begin{tabular}{|c|c|c|c|c|c|c|c|}
\hline \multirow[t]{2}{*}{ Response variable } & \multirow[t]{2}{*}{ Factor } & \multicolumn{3}{|c|}{ Analysis 1} & \multicolumn{3}{|c|}{ Analysis 2} \\
\hline & & df & $F$ & $P$ & df & $F$ & $\boldsymbol{P}$ \\
\hline \multirow[t]{4}{*}{ Total gnathiids } & Tide & 1 & 5.597 & 0.195 & & & \\
\hline & Tidal zone & 1 & 5.975 & 0.082 & 1 & 4.574 & 0.147 \\
\hline & Collection Period & 2 & $3 \cdot 329$ & 0.097 & 2 & 3.254 & 0.100 \\
\hline & Time of day & 4 & 3.876 & 0.037 & 4 & 3.164 & 0.038 \\
\hline \multirow[t]{4}{*}{ Stage 1 gnathiids } & Tide & 1 & 3.641 & 0.338 & & & \\
\hline & Tidal zone & 1 & 1.406 & 0.382 & & & \\
\hline & Collection Period & 2 & 4.662 & 0.063 & 2 & 5.880 & 0.041 \\
\hline & Time of day & 4 & 4.690 & 0.026 & 4 & 3.856 & 0.040 \\
\hline \multirow[t]{4}{*}{ Stage 2 gnathiids } & Tide & 1 & 4.367 & 0.278 & & & \\
\hline & Tidal zone & 1 & 5.457 & 0.095 & 1 & 3.007 & 0.191 \\
\hline & Collection Period & 2 & 3.178 & 0.150 & & & \\
\hline & Time of day & 4 & 2.394 & 0.085 & 4 & 2.894 & 0.047 \\
\hline \multirow[t]{4}{*}{ Stage 3 gnathiids } & Tide & 1 & 0.976 & 0.532 & & & \\
\hline & Tidal zone & 1 & 5.575 & 0.106 & & & \\
\hline & Collection Period & 2 & 2.759 & 0.136 & & & \\
\hline & Time of day & 4 & 1.409 & 0.173 & & & \\
\hline
\end{tabular}

Values in bold were considered significant at $P=0.01$ level in the first analysis. Those that met this criterion were used in the second analysis, and evaluated for significance at $P=0.05$ level and are in bold. 
Table 3. Posthoc pairwise time interval comparisons with Bonferroni adjustment for the total number of gnathiids $(\mathrm{df}=164)$ and stage $1(\mathrm{df}=165)$ and $2(\mathrm{df}=166)$ gnathiids at the $99.5 \%$ confidence interval.

\begin{tabular}{|c|c|c|c|c|c|c|c|}
\hline & Pairwise comparison & Estimate & SE & LB & UB & $t$-value & $P$ \\
\hline \multirow[t]{10}{*}{ Total gnathiids } & Afternoon-early evening & 1.569 & 0.923 & 0.062 & 5.930 & 1.699 & 0.091 \\
\hline & Afternoon-early morning & 2.0132 & 0.920 & 0.567 & 6.361 & 2.188 & 0.030 \\
\hline & Afternoon-evening & 2.001 & 0.904 & 0.597 & 6.313 & 2.215 & 0.028 \\
\hline & Afternoon-morning & -1.205 & 1.567 & -6.985 & 2.520 & 0.769 & 0.443 \\
\hline & Early evening-early morning & 0.445 & 0.397 & -0.853 & 1.663 & 1.119 & 0.265 \\
\hline & Early evening-evening & 0.433 & 0.382 & -0.819 & 1.751 & 1.105 & 0.271 \\
\hline & Early evening-morning & -2.774 & 1.357 & -11.525 & -0.357 & 2.044 & 0.043 \\
\hline & Early morning-evening & -0.012 & 0.361 & -1.169 & 1.227 & 0.033 & 0.974 \\
\hline & Early morning-morning & -3.219 & 1.325 & -21.177 & -0.874 & 2.429 & 0.016 \\
\hline & Evening-morning & -3.207 & 1.350 & -11.722 & -0.815 & 2.375 & 0.019 \\
\hline \multirow[t]{10}{*}{ Stage 1 gnathiids } & Afternoon-early evening & 0.566 & 0.295 & -0.272 & 1.664 & 1.919 & 0.057 \\
\hline & Afternoon-early morning & 0.305 & 0.327 & -0.747 & 1.333 & 0.933 & 0.352 \\
\hline & Afternoon-evening & 0.557 & 0.296 & -0.318 & 1.653 & 1.883 & 0.061 \\
\hline & Afternoon-morning & -2.151 & 1.200 & -10.200 & -0.088 & 1.793 & 0.075 \\
\hline & Early evening-early morning & -0.262 & 0.294 & -1.460 & 0.565 & 0.889 & 0.375 \\
\hline & Early evening-evening & -0.010 & 0.255 & -0.938 & 0.869 & 0.038 & 0.969 \\
\hline & Early evening-morning & -2.728 & 1.197 & -10.821 & -0.689 & 2.270 & 0.025 \\
\hline & Early morning-evening & 0.252 & 0.288 & -0.633 & 1.355 & 0.876 & 0.382 \\
\hline & Early morning-morning & -2.456 & 1.166 & -10.345 & -0.469 & 2.106 & 0.037 \\
\hline & Evening-morning & -2.708 & 1.190 & -10.542 & -0.680 & 2.275 & 0.024 \\
\hline \multirow[t]{10}{*}{ Stage 2 gnathiids } & Afternoon-early evening & 0.682 & 0.407 & 0.055 & 2.524 & 1.676 & 0.096 \\
\hline & Afternoon-early morning & 0.916 & 0.411 & 0.306 & 2.777 & 2.231 & 0.027 \\
\hline & Afternoon-evening & 0.931 & 0.404 & 0.336 & 2.783 & 2.305 & 0.022 \\
\hline & Afternoon-morning & 0.547 & 0.442 & -0.244 & 2.562 & 1.238 & 0.217 \\
\hline & Early evening-early morning & 0.235 & 0.117 & -0.018 & 0.699 & 2.009 & 0.046 \\
\hline & Early evening-evening & 0.250 & 0.115 & 0.007 & 0.741 & 2.180 & 0.031 \\
\hline & Early evening-morning & -0.135 & 0.216 & -0.974 & 0.341 & 0.622 & 0.535 \\
\hline & Early morning-evening & 0.015 & 0.070 & -0.200 & 0.238 & 0.215 & 0.830 \\
\hline & Early morning-morning & -0.369 & 0.202 & -1.352 & 0.019 & 1.825 & 0.070 \\
\hline & Evening-morning & -0.384 & 0.198 & -1.381 & -0.004 & 1.937 & 0.055 \\
\hline
\end{tabular}

the course of high tide probably aid in maintaining gnathiid abundance in that particular area. Gnathiids themselves may also contribute to their distribution as juvenile stage gnathiids are morphologically equipped for limited swimming (Smit et al., 1999). Models estimating movement distance of tropical gnathiids have reported they may move as much as $1.8 \mathrm{~m}$ to locate a host (Artim \& Sikkel, 2016). Since the combined distances fish and gnathiids can travel are within the boundaries of the entire intertidal zone, it is plausible that gnathiids are dispersed fairly evenly within the inter- and infratidal zones, and this is supported by our high $v s$ low tide and inter $v s$ infra tidal zone findings.

Unlike some tropical reef gnathiids, intertidal gnathiids in this study were most active during daytime hours. The diurnal activity of gnathiids is unexpected, given that their likely main predators, intertidal fishes, are also their prey and are mainly diurnal. Gnathiids may be most vulnerable to predation when they emerge from the benthos to infest a host, and when they detach from a host and return to the benthos to digest their blood meal. Accordingly, the time gnathiids spend infesting hosts may be the time at which gnathiids are least vulnerable to predation if hosts provide refuge from predators, especially in an environment with no known cleaner organisms (which would prey on gnathiids off of host fish). Gnathiids infesting hosts may evade predation from intertidal carnivorous fishes as most C. superciliosus are typically too large to serve as prey, and thus gnathiids on C. superciliosus would not be inadvertently depredated. Hence, the greatest predation risk for gnathiids is likely when they are in the water column (by filter feeders) or benthic substrate (by benthic dwellers). Ultimately, the hosts that gnathiids try to infest may utilize gnathiids as a prey resource, but $G$. africana have been reported to infest hosts' away from their head (Smit et al., 2003), which would reduce their chances of being seen and consumed by host fish. A further possibility is that the small number of gnathiids collected in this study is attributable to C. superciliosus having physiological defences against parasitism (Wisenden et al., 2009; Grutter et al., 2011b). To better understand gnathiid-host interactions, further comparative studies of $G$. africana and its interactions with diurnal and nocturnal fishes are needed.

The difference in peak activity time between intertidal and reef gnathiids may be reflected in functional morphological differences (Hammer, 1981; Nagel et al., 2008). Nocturnal reef gnathiids have been reported to have significantly longer antennules and larger eyes than diurnal reef gnathiids (Nagel et al., 2008; Nagel, 2009). Comparisons of G. africana eye size with other intertidal species, and the associations between their eye size and activity patterns have not been investigated.

Generally, we observed more first stage gnathiids than second and third stage gnathiids. This result is not surprising as it probably reflects a decline in gnathiid survivorship over the course of their life cycle (Smit et al., 2003; Artim \& Sikkel, 2016). The greater number of first stage gnathiids observed in April (autumn) and July (winter) compared with November (summer) may reflect the fact that females release their larvae more often during particular times of 
year. In part, this may suggest that intertidal gnathiids exhibit more seasonality than previously reported (Smit et al., 2003), but further research is needed to better understand if there are peak times for gnathiid reproduction. Nonetheless, this research suggests that G. africana release at least some larvae year round. To examine the factors associated with the timing of larval release and gnathiid survival, complementary field and laboratory studies are needed.

Perhaps the most important aspect of this research are the questions that have developed from our findings. Given that we now know that $G$. africana is a predominantly diurnal species, and that infection intensity on hosts is very low within tidal pools of TNP, a suite of studies examining what regulates the timing of G. africana activity as well as their functional role and significance in intertidal trophic dynamics are needed. While obtaining these data are difficult given the high-wave action of intertidal systems, our study is the first to provide information about the timing and distribution of temperate intertidal gnathiids. Thus the findings of this research can facilitate the successful implementation of future temperate intertidal gnathiid ecology studies.

\section{ACKNDWLEDGEMENTS}

We thank former and current members of the Water Research Group of North-West University and University of Johannesburg for their assistance in the field. We express gratitude for the assistance in project development by the late Angela Davies-Russell. We thank South Africa National Parks for their assistance with and permitting of this project, entitled 'Biodiversity, Ecology, and Systematics of Gnathiid Isopoda (Crustacea) Parasitic on Marine Fishes of South Africa, PI NJ Smit, 2006-2011'. This is contribution number 201 from the NWU-Water Research Group.

\section{FINANCIAL SUPPORT}

Financial support from the Claude Leon Foundation of South Africa for Rachel L. Welicky made this research possible. Financial assistance of South Africa's National Research Foundation (NRF) towards this research is hereby acknowledged (NRF Project IFR170210222411, NJ Smit, PI). Opinions expressed and conclusions arrived at, are those of the authors and are not necessarily to be attributed to the NRF.

\section{REFERENCES}

Abelson A. and Denny M. (1997) Settlement of marine organisms in flow. Annual Review of Ecology and Systematics 28, 317-339.

Artim J.M., Sellers J.C. and Sikkel P.C. (2015) Micropredation by gnathiid isopods on settlement-stage reef fish in the eastern Caribbean Sea. Bulletin of Marine Science 4, 479-487.

Artim J.M. and Sikkel P.C. (2016) Comparison of sampling methodologies and estimation of population parameters for a temporary fish ectoparasite. International Journal for Parasitology: Parasites and Wildlife 5, 145-157.

Bennett B.A. (1984) A population energy budget for Clinus superciliosus L., with an assessment of the role of resident fish as predators in the intertidal zone. Marine Biology Letters 5, 323-334.
Bennett B., Griffiths C.L. and Penrith M.L. (1983) The diets of littoral fish from the Cape Peninsula. South African Journal of Zoology 18, $343-352$.

Bunkley-Williams L. and Williams E.H. (1998) Isopods associated with fishes: a synopsis and corrections. Journal of Parasitology 84, 893-896.

Chambers S.D. and Sikkel P.C. (2002) Diel emergence patterns of ecologically important, fish-parasitic, gnathiid isopod larvae on Caribbean coral reefs. Caribbean Journal of Science 38, 37-43.

Cohen J.H. and Forward R.B. Jr (2009) Zooplankton diel vertical migration - a review of proximate control. Oceanography and Marine Biology: An Annual Review 47, 77-110.

Coile A.M. and Sikkel P.C. (2013) An experimental field test of susceptibility to ectoparasitic gnathiid isopods among Caribbean reef fishes. Parasitology 140, 888-896.

Coile A.M., Welicky R.L. and Sikkel P.C. (2014) Female Gnathia marleyi (Isopoda: Gnathiidae) feeding on more susceptible fish hosts produce larger but not more offspring. Parasitology Research 113, 3875-3880.

Connor K.M. and Gracey A.Y. (2011) Circadian cycles are the dominant transcriptional rhythm in the intertidal mussel Mytilus californianus. Proceedings of the National Academy of Sciences USA 108, 1611016115 .

Côté I.M. (2000) Evolution and ecology of cleaning symbioses in the sea. Oceanography and Marine Biology 38, 311-355.

Côté I.M. and Molloy P.P. (2003) Temporal variation in cleanerfish and client behaviour: does it reflect ectoparasite availability? Ethology 109, 487-499.

Curtis L.M., Grutter A.S., Smit N.J. and Davies A.J. (2013) Gnathia aureamaculosa, a likely definitive host of Haemogregarina balistapi and potential vector for Haemogregarina bigemina between fishes of the Great Barrier Reef, Australia. International Journal for Parasitology $43,361-370$.

Davies A.J. and Smit N.J. (2001) The life cycle of Haemogregarina bigemina (Adeleina: Haemogregarinidae) in South African hosts. Folia Parasitologica 48, 169-177.

Davies A.J., Smit N.J., Hayes P.M., Seddon A.M. and Wertheim D. (2004) Haemogregarina bigemina (Protozoa: Apicomplexa: Adeleorina) past, present and future. Folia Parasitologica 51, 99-108.

Farquharson C., Smit N.J. and Sikkel P.C. (2012) Gnathia marleyi sp. nov. (Crustacea, Isopoda, Gnathiidae) from the eastern Caribbean. Zootaxa 3381, 47-61.

Ferreira M.L., Smit N.J. and Davies A.J. (2010) Gnathia grutterae sp. nov. (Crustacea, Isopoda, Gnathiidae) parasitising representatives of the Balistidae, Labridae and Tetraodontidae from Lizard Island, Great Barrier Reef, Australia. Zootaxa 2718, 39-50.

Ferreira M.L., Smit N.J., Grutter A.S. and Davies A.J. (2009) A new species of gnathiid (Crustacea: Isopoda) parasitizing teleosts from Lizard Island, Great Barrier Reef, Australia. Journal of Parasitology $95,1066-1075$.

Gibbons M.J. (1988) Impact of predation by juvenile Clinus superciliosus on phytal meiofauna: are fish important as predators? Marine Ecology Progress Series 45, 13-22.

Gibson R.N. (2003) Go with the flow: tidal migration in marine animals. Hydrobiologia 503, 153-191.

Gilbert J.J. and Hampton S.E. (2001) Diel vertical migrations of zooplankton in a shallow, fishless pond: a possible avoidance-response cascade induced by notonectids. Freshwater Biology 46, 611-621.

Grutter A.S. (1994) Spatial and temporal variations of the ectoparasites of seven coral reef fish from Lizard Island and Heron Island, Australia. Marine Ecology Progress Series 115, 21-30. 
Grutter A.S. (1999) Infestation dynamics of parasitic gnathiid isopod juveniles on a coral reef fish Hemigymnus melapterus. Marine Biology 135, 545-552.

Grutter A.S. (2002) Cleaning behaviour from the parasite's perspective. Parasitology 124, S65-S81.

Grutter A.S. (2008) Interactions between gnathiid isopods, cleaner fish and other fishes on Lizard Island, Great Barrier Reef. Journal of Fish Biology 73, 2094-2109.

Grutter A.S., Crean A.J., Curtis L.M., Kuris A.M., Warner R.R. and McCormick M.I. (2011a) Indirect effects of an ectoparasite reduce successful establishment of a damselfish at settlement. Functional Ecology 25, 586-594.

Grutter A.S. and Hendrikz J. (1999) Diurnal variation in the abundance of juvenile parasitic gnathiid isopods on coral reef fish: implications for parasite-cleaner fish interactions. Coral Reefs 18, 187-191.

Grutter A.S., Lester R.J.G. and Greenwood J. (2000) Emergence rates from the benthos of the parasitic juveniles of gnathiid isopods. Marine Ecology Progress Series 207, 123-127.

Grutter A.S., Pickering J.L., McCallum H. and McCormick M.I. (2008) Impact of micropredatory gnathiid isopods on young coral reef fishes. Coral Reefs 27, 655-661.

Grutter A.S. and Poulin R. (1998a) Cleaning of coral reef fishes by the wrasse Labroides dimidiatus: ecological and phylogenetic influences. Copeia 1998, 120-127.

Grutter A.S. and Poulin R. (1998b) Intraspecific and interspecific relationships between host size and the abundance of parasitic larval gnathiid isopods on coral reef fish. Marine Ecology Progress Series $164,263-271$

Grutter A.S., Rumney J.G., Sinclair-Taylor T., Waldie P. and Franklin C.E. (2011b) Fish mucous cocoons: the 'mosquito nets' of the sea Biology Letters 7, 292-294.

Hadfield K.A., Smit N.J. and Avenant-Oldewage A. (2008) Gnathia pilosus sp. nov. (Crustacea, Isopoda, Gnathiidae) from the East Coast of South Africa. Zootaxa 1894, 23-41.

Hadfield K.A., Smit N.J. and Avenant-Oldewage A. (2009) Life cycle of the temporary fish parasite, Gnathia pilosus (Crustacea: Isopoda: Gnathiidae) from the east coast of South Africa. Journal of the Marine Biological Association of the United Kingdom 89, 1331-1339.

Hammer R.M. (1981) Day-night differences in the emergence of demersal zooplankton from a sand substrate in a kelp forest. Marine Biology $62,275-280$.

Hammer R.M. and Zimmerman R.C. (1979) Species of demersal zooplankton inhabiting a kelp forest ecosystem off Santa Catalina Island, California. Bulletin of the California Academy of Sciences 78 199-206.

Hayes P.M., Smit N.J., Grutter A.S. and Davies A.J. (2011) Unexpected response of a captive blackeye thicklip, Hemigymnus melapterus (Bloch), from Lizard Island, Australia, exposed to juvenile isopods Gnathia aureamaculosa Ferreira \& Smit. Journal of Fish Diseases 34, $563-566$.

Hays G.C. (1995) Ontogenetic and seasonal variation in the diel vertical migration of the copepods Metridia lucens and Metridia longa. Limnology and Oceanography 40, 1461-1465.

Hays G.C. (2003) A review of the adaptive significance and ecosystem consequences of zooplankton diel vertical migrations. Hydrobiologia $503,163-170$.

Hobson E.S. and Chess J.R. (1976) Trophic interactions among fishes and zooplankters near shore at Santa Catalina Island, California. Fishery Bulletin 74, 567-598.
Jacoby C.A. and Greenwood J.G. (1988) Spatial, temporal, and behavioural patterns in emergence of zooplankton in the lagoon of Heron Reef, Great Barrier Reef. Marine Biology 97, 309-328.

Jones C.M. and Grutter A.S. (2005) Parasitic isopods (Gnathia sp.) reduce haematocrit in captive blackeye thicklip (Labridae) on the Great Barrier Reef. Journal of Fish Biology 66, 860-864.

Jones C.M. and Grutter A.S. (2007) Variation in emergence of parasitic and predatory isopods among habitats at Lizard Island, Great Barrier Reef. Marine Biology 150, 919-927.

Jones C.M., Nagel L., Hughes G.L., Cribb T.H. and Grutter A.S. (2007) Host specificity of two species of Gnathia (Isopoda) determined by DNA sequencing blood meals. International Journal for Parasitology $37,927-935$.

Marsh B., Crowe T.M. and Siegfried W.R. (1978) Species richness and abundance of clinid fish (Teleostei; Clinidae) in intertidal rock pools. Zoologica Africana 13, 283-291.

Nagel L. (2009) The role of vision in host-finding behaviour of the ectoparasite Gnathia falcipenis (Crustacea; Isopoda). Marine and Freshwater Behaviour and Physiology 42, 31-42.

Nagel L. and Grutter A.S. (2007) Host preference and specialization in Gnathia sp., a common parasitic isopod of coral reef fishes. Journal of Fish Biology 70, 497-508.

Nagel L., Montgomerie R. and Lougheed S. (2008) Evolutionary divergence in common marine ectoparasites Gnathia spp. (Isopoda: Gnathiidae) on the Great Barrier Reef: phylogeography, morphology, and behavior. Biological Journal of the Linnean Society 94, 569-587.

Naylor E. (1999) Marine animal behaviour in relation to lunar phase. Earth, Moon, and Planets 85, 291-302.

Palmer J.D. (2000) The clocks controlling the tide-associated rhythms of intertidal animals. BioEssays 22, 32-37.

Penfold R., Grutter A.S., Kuris A.M., McCormick M.I. and Jones C.M. (2008) Interactions between juvenile marine fish and gnathiid isopods: predation $v s$ micropredation. Marine Ecology Progress Series $357,111-119$.

Poulin R. (2000) Variation in the intraspecific relationship between fish length and intensity of parasitic infection: biological and statistical causes. Journal of Fish Biology 56, 123-137.

Reebs S.G. (2002) Plasticity of diel and circadian activity rhythms in fishes. Reviews in Fish Biology and Fisheries 12, 349-371.

Sancho G., Solow A.R. and Lobel P.S. (2000) Environmental influences on the diel timing of spawning in coral reef fishes. Marine Ecology Progress Series 206, 193-212.

Sauer W.H.H., Penney A.J., Erasmus C., Mann B.Q., Brouwer S.L., Lamberth S.J. and Stewart T.J. (1997) An evaluation of attitudes and responses to monitoring and management measures for the South African boat-based line fishery. South African Journal of Marine Science 18, 147-163.

Sikkel P.C., Cheney K.L. and Côté I.M. (2004) In situ evidence for ectoparasites as a proximate cause of cleaning interactions in reef fish. Animal Behaviour 68, 241-247.

Sikkel P.C., Herzlieb S.E. and Kramer D.L. (2005) Compensatory cleaner-seeking behavior following spawning in female yellowtail damselfish. Marine Ecology Progress Series 296, 1-11.

Sikkel P.C., Shaumburg C.S. and Mathenia J.K. (2006) Diel infestation dynamics of gnathiid isopod larvae parasitic on Caribbean reef fish. Coral Reefs 25, 683-689.

Sikkel P.C. and Welicky R.L. (in press). The ecological significance of parasitic crustaceans. In: Marine Parasites. 
Sikkel P.C., Welicky R.L., Artim J.M., McCammon A.M., Sellers J.C., Coile A.M. and Jenkins W.G. (2017) Nocturnal migration reduces exposure to micropredation in a coral reef fish. Bulletin of Marine Science 93, 475-489. Available online.

Sikkel P.C., Ziemba R.E. and Sears W.T. (2009) Diel ontogenetic shift in parasitic activity in a gnathiid isopod on Caribbean coral reefs. Coral Reefs 28, 489-495.

Smit N.J., Basson L. and Van As J.G. (2003) Life cycle of the temporary fish parasite, Gnathia africana (Crustacea: Isopoda: Gnathiidae). Folia Parasitologica 50, 135-142.

Smit N.J. and Davies A.J. (1999) New host records for Haemogregarina bigemina from the coast of southern Africa. Journal of the Marine Biological Association of the United Kingdom 79, 933-935.

Smit N.J. and Davies A.J. (2004) The curious life-style of the parasitic stages of gnathiid isopods. Advances in Parasitology 58, 289-391.

Smit N.J., Van As J.G. and Basson L. (1999) A redescription of the adult male and praniza of Gnathia africana Barnard, 1914 (Crustacea, Isopoda, Gnathiidae) from southern Africa. Folia Parasitologica 46, 229-240.

Smit N.J., Van As J.G. and Basson L. (2002) Redescription of the female of Gnathia africana (Crustacea: Isopoda: Gnathiidae) from southern Africa. Folia Parasitologica 49, 67-72.

Smith M.M. and Heemstra P.C. (2003) Smiths' sea fishes. Cape Town: Struik Publishers.

Stuart-Smith R.D., Bates A.E., Lefcheck J.S., Duffy J.E., Baker S.C., Thomson R.J., Stuart-Smith J.F., Hill N.A., Kininmonth S.J., Airoldi L. and Becerro M.A. (2013) Integrating abundance and functional traits reveals new global hotspots of fish diversity. Nature 501, 539-542.

Tanaka K. and Aoki M. (1998) Crustacean infauna of the demosponge Halichondria okadai (Kadota) with reference to the life cycle of Gnathia sp. (Isopoda: Gnathiidea). In Watanabe Y. and Fusetani N. (eds) Sponge Science: Multidisciplinary Perspectives. Tokyo: SpringerVerlag, pp. 259-267.

Tanaka K. and Aoki M. (1999) Spatial distribution patterns of the sponge-dwelling gnathiid isopod Elaphognathia cornigera (Nunomura) on an intertidal rocky shore of the Izu Peninsula, southern Japan. Crustacean Research 28, 160-167.

Tessmar-Raible K., Raible F. and Arboleda E. (2011) Another place, another timer: marine species and the rhythms of life. Bioessays 33, $165-172$.

Triki Z., Grutter A.S., Bshary R. and Ros A.F. (2016) Effects of shortterm exposure to ectoparasites on fish cortisol and hematocrit levels. Marine Biology 163, 187.

Turpie J., Clark B. and Hutchings K. (2006) The economic value of Marine Protected Areas along the Garden Route Coast, South Africa, and implications of changes in size and references management. Cape Town: Anchor Environmental Consultants and Percy FitzPatrick Institute, University of Cape Town.

Waldie P.A., Blomberg S.P., Cheney K.L., Goldizen A.W. and Grutter A.S. (2011) Long-term effects of the cleaner fish Labroides dimidiatus on coral reef fish communities. PLoS ONE 6, e21201.

Welicky R.L., Cheney K.L., Coile A.M., McCammon A. and Sikkel P.C. (2013) The relationship between lunar periodicity and activity of fishparasitic gnathiid isopods in the Caribbean. Marine Biology 160, $1607-1617$.

Wisenden B.D., Goater C.P. and James C.T. (2009) Behavioral defenses against parasites and pathogens. In Zaccone G., Perrière M.A. and Kapoor B.G. (eds) Fish defenses. Boca Raton, FL: CRC Press, pp. $151-168$.

and

Zemke-White W.L., Choat J.H. and Clements K.D. (2002) A re-evaluation of the diel feeding hypothesis for marine herbivorous fishes. Marine Biology 141, 571-579.

\section{Correspondence should be addressed to:}

R. L. Welicky

Water Research Group, Unit for Environmental Sciences and Management, North-West University, Potchefstroom Campus, Private Bag X6001, Potchefstroom, 2520, South Africa email: rwelicky@gmail.com 